\title{
Gestational Trophoblastic Tumor Pathologic TNM Finding v7
}

National Cancer Institute

\section{Source}

National Cancer Institute. Gestational Trophoblastic Tumor Pathologic TNM Finding v7. NCI Thesaurus. Code C89694.

A pathologic finding about one or more characteristics of gestational trophoblastic tumor, following the rules of the TNM AJCC V7 classification system. 